\title{
Molecular phylogeny and re-assessment of some Scleroderma spp. (Gasteromycetes)
}

\author{
by \\ Cherdchai Phosri ${ }^{1}$, María P. Martín², Roy Watling ${ }^{3}$, Mikael Jeppson ${ }^{4} \&$ Prakitsin Sihanonth $^{5}$ \\ ${ }^{1}$ Microbiology programme, Faculty of Science\& Technology, Pibulsongkram Rajabhat University, Phitsanulok, 65000, Thailand. \\ cherd_phosri@yahoo.co.uk \\ ${ }^{2}$ Departamento de Micología, Real Jardín Botánico, CSIC, Plaza de Murillo 2, E-28014 Madrid, Spain. maripaz@rib.csic.es \\ 3 Caledonian Mycological Enterprises, Crelah, 26 Blinkbonny Ave, Edinburgh, EH4 3HU, Scotland. caledonianmyc@blueyonker.co.uk \\ ${ }^{4}$ Lilla Håjumsgatan 4, S-461 35 Trollhättan, Sweden. jeppson@svampar.se \\ 5 Department of Microbiology, Faculty of Science, Chulalongkorn University, 10330 Bangkok, Thailand. Prakitsin.S@Chula.ac.th
}

\begin{abstract}
Phosri, C., Martín, M.P., Watling, R., Jeppson, M. \& Sihanonth, P. 2009. Molecular phylogeny and re-assessment of some Scleroderma spp. Anales Jard. Bot. Madrid. 66S1: 83-91.

The fungal genus Scleroderma is cosmopolitan in temperate and tropical regions and forms ectomycorrhizal associations with a wide range of forest trees. To delimit phylogenetic Scleroderma species and identification, 43 basidiomes were chosen of different geographical origins and their rDNA internal transcribed spacer (ITS) were sequenced. Phylogenetic analyses of these sequences together with additional GenBank sequences identified 11 taxa. A strong phylogenetic pattern was observed related to a character of their basidiospore ornamentation.
\end{abstract}

Keywords: Boletales, ecology, ectomycorrhizal fungi, gasteromycete, Scleroderma, taxonomy, phylogenetic species.

\section{Introduction}

Scleroderma was first introduced by Persoon (1801) with 11 species. The first $S$. pistillare L.: Pers. is now placed in Podaxis Desv. The second $S$. herculeum Pers. is placed in Pisolithus (Alb. \& Schwein). The third, S. carcinomarlis L., is considered a synonym of Podaxis pistillaris (L.: Pers.) Morse. and fourth and fifth S. tinctorius Mich.: Pers. and S. arbizus Pers. respectively are considered at present to represent the same species, now placed in Pisolithus. This leaves a remaining six species of which $S$. aurantiacum Pers. and $S$. citrinum Pers, are now considered the same (Guzmán, 1970), under the latter name, S. verrucosum

\section{Resumen}

Phosri, C., Martín, M.P., Watling, R., Jeppson, M. \& Sihanonth, P. 2009. Filogenia molecular y reevaluación de algunas especies de Scleroderma. Anales Jard. Bot. Madrid. 66S1: 83-91 (en inglés).

Las especies del género Scleroderma son cosmopolitas y forman ectomicorrizas con un amplio rango de hospedantes, tanto de zonas templadas como tropicales. Para delimitar las especies filogenéticas y la identificación de las mismas, se han seleccionado 43 basidiomas, de diferente origen geográfico, y se han secuenciado las regiones de transcripción interna del ADN ribosómico nuclear. Los análisis filogenéticos de estas colecciones, junto con secuencias obtenidas del GenBank, permiten identificar 11 especies, agrupadas en tres clados relacionados con el tipo de ornamentación de la basidióspora.

Palabras clave: Boletales, ecología, especies filogenéticas, gasteromicete, hongo ectomicorrícico, Scleroderma, taxonomía.

(Vaill.) Pers. and S. spadiceum Schaeff.: Pers., with this last species considered a nomen confusum (Guzmán, 1970), S. cepa Pers. and S.cervinum (L.) Pers. S. cervinum undoubtedly is referable to the ascomycetous genus Elaphomyces (Guzmán, 1970). As presently understood Scleroderma is restricted to Persoon's S. citrinum and $S$. verrucosum consortia. At least 25 species is classified within the Sclerodermataceae (Hawksworth \& al., 1995; Sims \& al., 1995).

The characters which have been extensively used to separate the species within the genus are the thickness and the scaliness of the peridium and whether the basidiome is stalked or not, and if the former the structure of the stipe. In the case of $S$. polyrbizum (J.F. Gmel.) 
Pers. the shape of the basidiome in old age is also important. These characters at a later date were combined with the size of the basidiospores and their ornamentation and in the latter case whether the ornamentation is composed of isolated spines or warts or forms a reticulum. The spines may be narrow or broadly based or the reticulum complete and very distinctive or incomplete. Vaillant (1727) in 'Botanicon Parisiensis' was probably the first author to recognize a species of Scleroderma, viz. S. citrinum in the phrase 'Lycoperdon ornati colores ad basim rugosum' but even after that date confusion between the puff-balls and the earth-balls persisted to which Fries (1821) blamed Micheli in his lumping.

Many publications include species of Scleroderma but it was Šebek (1953) who first attempted a consolidation of the known facts based on Czechoslovakian collections. Although this author gave an excellent account of the history of the genus his interpretation of the specific names was very different to that accepted by the classical authors and that in current use in other European countries. It was not until 1970 that the genus was fully monographed (Guzmán, 1970) and his concepts have generally stood the test of time. Guzmán (1970) also gave a good historical account of the genus and the various fungi assigned to it over the years.

Guzmán (1970) divided the genus into three subgenera, those species with spiny basidiospores ( $\mathrm{Acu}$ leatispora), those with subreticulate basidiospores (Sclerangium) and those with distinctly reticulate basidiospores (Scleroderma). Fries (1821) stated 'still doubt the possibility of an easy solution of the taxonomic position of the species in the genus Scleroderma which had been very negligently worked at the time' - fide Šebek (1953). Although much work has been carried out since this statement was made there are still some problems in the circumscription of some constituent taxa, viz. S. verrucosum (Bull.: Pers)/S. cepa Pers.: Pers and S. bovista Fr. and its relatives especially the recently described $S$. septentrionale Jeppson from Northern Europe.

The present article attempts to examine the broad division of Scleroderma using molecular techniques and to try and resolve the differences experienced whilst examining material of the taxa noted above. Included in this work are collections of the type species of the genus, $S$. citrinum. Two members of the subgenus Sclerangium i.e. S. sinnamariense Mont. and S. polyrhizum from Thailand and North America respectively are added to the analysis.

\section{Materials and methods}

\section{Fungal Isolates}

The Scleroderma samples used in this work were either fresh, cultured or herbarium specimens. They were collected from a variety of geographical origins (Table 1). Basidiomes for each collection were retained in the herbarium at the Biology Programme, Faculty of Science \& Technology, Pibulsongkram Rajabhat University, Thailand. Cultures obtained from basidiomata were grown and maintained on Modified Melin Norkrans' (MMN) medium (Marx, 1981) at $30{ }^{\circ} \mathrm{C}$ with subculturing every $1-2$ months. Herbarium specimens were provided by BCN, E, and A.D. Parker Herbarium in Wisconsin for comparison with those collections cultured. Basidiospores ornamentation was analysed using scanning electron microscopy (SEM). Samples were air-dried and sputtercoated with gold and examined with JEOL JSM-840 scanning electron microscope.

\section{Molecular methods}

Samples for DNA extraction were excised from fresh or dry basidiomes or the outer part of mycelium agar culture. To avoid contamination by other fungi, tissues were taken from the inner part of the basidiome. DNA was isolated from each sample with the E.Z.N.A. fungi DNA miniprep kit (Omega Biotech, GA, USA) as described by Martín \& García-Figueres (1999). The ITS regions were amplified with ReadyTo-Go ${ }^{\mathrm{TM}}$ PCR Beads (GE healthcare Life Sciences, NJ, USA) (Martín \& Winka, 2000). Primer pairs ITS1F/ITS4B and ITS1/ITS4 were used for amplification of the ITS regions including the $5.8 \mathrm{~S}$ of the ribosomal RNA gene cluster, as described by White \& al. (1990) and Gardes \& Bruns (1993). When no products were obtained with these primer pairs, ITS2 and ITS3 (White \& al. 1990) were used in different combinations with the primers mentioned above, to amplify the two ITS regions separately. A negative control was prepared in each series of amplifications in order to detect possible contamination in the reagents. The PCR was performed using a PE 9700 DNA thermocycler (Perkin Elmer Applied Biosystems, MA, USA). The cycling parameters were five cycles of denaturation at $94{ }^{\circ} \mathrm{C}$ for $30 \mathrm{~s}$, annealing at $55^{\circ} \mathrm{C}$ for $30 \mathrm{~s}$ and extension at $72{ }^{\circ} \mathrm{C}$ for $1 \mathrm{~min}$, followed by 33 cycles of denaturation at $94{ }^{\circ} \mathrm{C}$ for $30 \mathrm{~s}$, annealing at $48^{\circ} \mathrm{C}$ for $30 \mathrm{~s}$ and extension at $72{ }^{\circ} \mathrm{C}$ for $1 \mathrm{~min}$, with a final extension at $72{ }^{\circ} \mathrm{C}$ for $10 \mathrm{~min}$. Before initiating the cycling parameters, an initial denaturation at $94{ }^{\circ} \mathrm{C}$ for 5 min was done. PCR products were analysed by electrophoresis on $2 \%$ agarose gels 
Table 1. List of Scleroderma and Pisolithus sp. collections.

\begin{tabular}{|c|c|c|c|c|c|}
\hline Name & $\begin{array}{l}\text { DNA } \\
\text { isolation } \\
\text { code }\end{array}$ & $\begin{array}{c}\text { Herbarium } \\
\text { No. }\end{array}$ & Origin & $\begin{array}{c}\text { Collection } \\
\text { date }\end{array}$ & $\begin{array}{c}\text { Genbank } \\
\text { Accession } \\
\text { No. }\end{array}$ \\
\hline Pisolithus sp. & PISOLI3 & BCN-MPM2676 & Catalonia, Spain & $-/ 10 / 1997$ & FM213365 \\
\hline Sclerodema areolatum & ARESCL_1 & E00278288 & Sheboygan county, WI., USA & 05/09/1998 & FM213351 \\
\hline S. areolatum & ARESCL_2 & E00278290 & Sheboygan county, WI., USA & 05/09/1998 & FM213352 \\
\hline S. areolatum & ARESCL_3 & E00278286 & Dane county, WI., USA & 08/09/2001 & FM213353 \\
\hline S. bovista & BOVSCL_1 & BCN-MPM1989 & Catalonia,Spain & 12/07/1995 & FM213340 \\
\hline S. cf. bovista & BOVSCL_2 & BOVSCL_2 & Richland county, WI., USA & 03/10/1993 & FM213339 \\
\hline S. cepa & CEPSCL_1 & BCN-MPM2603 & Catalonia, Spain & 20/10/1996 & - \\
\hline S. cepa & CEPSCL_2 & BCN-MPM2525 & Catalonia, Spain & 26/11/1995 & FM213354 \\
\hline S. cepa & CEPSCL_3 & BCN-MPM2526 & Catalonia, Spain & 01/05/1995 & - \\
\hline S. сера & CEPSCL_4 & E00278292 & Dane county, WI., USA & 08/09/2001 & - \\
\hline S. сера & CEPSCL_5 & E00278296 & Adam county, WI., USA & 21/09/2001 & FM213355 \\
\hline S. сера & CEPSCL_6 & MJ1926 & V. Tunhem, Sweden & $30 / 8 / 1985$ & - \\
\hline S. citrinum & CITSCL_1 & E00278300 & Adam county, WI., USA & 20/09/1985 & FM213344 \\
\hline S. citrimum & CITSCL_2 & - & Dane county, WI., USA & 22/09/2001 & FM213345 \\
\hline S. citrinum & UNSCL_2 & $\mathrm{SCL3}$ & Dawyck, Scotland & 28/01/2002 & FM213333 \\
\hline S. citrinum & UNSCL_3 & SCL5 & Dawyck, Scotland & $28 / 01 / 2002$ & FM213334 \\
\hline S. citrinum & UNSCL_4 & $\mathrm{SCL7}$ & Dawyck, Scotland & 28/01/2002 & FM213335 \\
\hline S. michiganense & MICSCL_1 & E00278306 & Sheboygan county, WI., USA & 14/09/1991 & FM213346 \\
\hline S. michiganense & MICSCL_2 & E00278311 & Sheboygan county, WI., USA & 05/09/1998 & FM213347 \\
\hline S. michiganense & MICSCL_3 & E00278309 & Waukesha county, WI., USA & 30/08/1992 & FM213348 \\
\hline S. polyrhizum & POLSCL_1 & E00278315 & Grant county, WI., USA & 23/09/2001 & FM213349 \\
\hline S. polyrhizum & POLSCL_2 & E00278313 & Richland county, WI., USA & $10 / 10 / 2000$ & FM213350 \\
\hline S. cf. septentrionale & SEPSCL_1 & E00278318 & Adam county, WI., USA & $14 / 10 / 2000$ & FM213337 \\
\hline S. septentrionale & SEPSCL_2 & J. Nitare (12.9.1986) & Norrbotten, Sweden & 12/09/1986 & FM213336 \\
\hline S. septentrionale & SEPSCL_3 & A.D. Parker (2.10.1997) & Lone Rock, Wl., USA & 02/10/1997 & FM213338 \\
\hline S. sinnamariense & SINSCL_1 & SCLK4 & Hot, Chiang Mai, Thailand & $28 / 01 / 2002$ & FM213356 \\
\hline S. sinnamariense & SINSCL_2 & SCLP3 & Hot, Chiang Mai, Thailand & $28 / 01 / 2002$ & FM213357 \\
\hline S. sinnamariense & SINSCL_3 & SCLN & Hot, Chiang Mai, Thailand & 28/01/2002 & FM213358 \\
\hline S. sinnamariense & SINSCL_4 & SCLY5 & Hot, Chiang Mai, Thailand & $28 / 01 / 2002$ & FM213359 \\
\hline S. sinnamariense & SINSCL_5 & SC1 & Hot, Chiang Mai, Thailand & 28/01/2002 & FM213360 \\
\hline S. sinnamariense & SINSCL_6 & SCLD1 & Hot, Chiang Mai, Thailand & 28/01/2002 & FM213361 \\
\hline S. sinnamariense & SINSCL_7 & SINSCL_7 & Muang, Yasothon, Thailand & $12 / 08 / 2001$ & FM213362 \\
\hline S. sinnamariense & SINSCL_8 & SINSCL_8 & Pranomprai, Roi Et, Thailand & 22/08/2001 & FM213363 \\
\hline S. sinnamariense & SINSCL_9 & SINSCL_9 & Muang, Yasothon, Thailand & $24 / 08 / 2001$ & FM213364 \\
\hline Scleroderma sp. & UNSCL_5 & E00278667 & Juneau county, WI., USA & 25/09/1993 & FM213342 \\
\hline Scleroderma sp. & UNSCL_6 & E00278668 & Adam county, WI., USA & $14 / 10 / 2000$ & - \\
\hline Scleroderma sp. & UNSCL_7 & - & Hot, Chiang Mai, Thailand & $11 / 12 / 2001$ & FM213343 \\
\hline Scleroderma sp. & UNSCL_8 & MJ6006 & Orgovány, Hungary & $01 / 11 / 2002$ & FM213341 \\
\hline Scleroderma sp. & UNSCL_1 & $\mathrm{SCB}$ & Hot, Chiang Mai, Thailand & 28/01/2002 & - \\
\hline S. verrucosum & VERSCL_1 & BCN-MPM1737 & Catalonia, Spain & 16/11/1993 & - \\
\hline S. verrucosum & VERSCL_2 & BCN-MPM2523 & Catalonia, Spain & 31/10/1995 & - \\
\hline S. verrucosum & VERSCL_3 & BCN-MPM2529 & Catalonia, Spain & 06/11/1995 & - \\
\hline S. verrucosum & VERSCL_4 & BCN-MPM2605 & Catalonia, Spain & 29/09/1996 & AJ629886 \\
\hline
\end{tabular}


on $1 \times$ Tris-acetate buffer (Sambrook \& al., 1989) and visualized by staining with ethidium bromide. Products were cleaned directly using E.Z.N.A. Clean kit (Omega Biotech) or from the gel using QIAQuick PCR purification kit (QIAGEN, Chatsworth, CA). All samples were sequenced in both directions. The primers used for sequencing were ITS1, ITS2, ITS3 and ITS4. Aliquots of the purified products were mixed separately with the direct and reverse primers before sending to the Secugen company (Madrid, Spain) for sequencing. When weak PCR products were obtained, the products were cleaned from the gel using QIAquick Gel (QIAGEN) cloned with pGEM®-T Easy Vector Systems (Promega, Madison, WI) and purified with QIAPrep Spin Mini prep (QIAGEN). To confirm that the correct product had been inserted, $2 \mu \mathrm{l}$ of the purified sample was digested with Eco RI following the instructions of the manufacture. Both strands were sequenced separately using vector specific primers T7 and M13 in the Secugen company.

Sequences analysis: Sequences from each sample was assembled to obtain the consensus sequence of the ITS1, 5.8S and ITS2 nrDNA using Navigator ${ }^{\mathrm{TM}}$ Sequence comparison software (Perkin Elmer Applied Biosystem) or Sequencher (Gene Codes Coorporation Inc, Ann Arbor, Michigan, USA). Multiple sequences alignment of the ITS regions from different collection with selected Scleroderma ITS sequences obtained from GenBank DNA database (http://www.ncbi.nlm.nih.gov/entrez/) i.e. S. bovista (AB211267 \& AB099901), S. cepa (DQ453694) and S. citrinum (AY935514) were performed using the SEQAPP software (Perkin Elmer Applied Biosystem). The alignment was optimized visually. Alignment gaps were indicated as "_" and ambiguous nucleotides were marked as "N".

Phylogenetic analyses: The alignment was analysed using the programme PAUP 4.0b10 (Swofford, 2003) and MrBAYES 3.0 (Huelsenbeck \& Ronquist, 2001). Pisolithus sp. (Martin \& al., 2002, clade of Pisolithus sp.4) was used as outgroup taxon as this species is closely related to Scleroderma (Binder \& Bresinsky 2002). First a parsimony analysis under a heuristic search was conducted to analyse the phylogenetic relationships between the Scleroderma samples. Gaps were treated as missing data. The tree branch robustness was estimated by bootstrap (BS) analysis (Felsenstein, 1985) employing 10K replicates, using the fast-step option. The starting branch lengths were obtained using the Roger-Swofford approximation method and the starting trees for branch swapping were obtained by stepwise addition. The tree bisection-reconnection (TBR) branch-swapping algorithm was used with the Multrees options in effect. The data were further analysed using a Bayesian approach (Huesenback \& al., 2000; Larget \& Simon, 1999). The posterior probabilities (PP) were approximated by sampling trees using a MCMC method. The Bayesian analysis was performed assuming the general time reversible model (Rodriguez \& al., 1990) including estimation of invariant sites and assuming a discrete gamma distribution with six rate categories $(\mathrm{GTR}+\mathrm{I}+\mathrm{G})$. A run with $2 \mathrm{M}$ generation starting with a random tree and employing 12 simultaneous chains was executed. Every $100^{\text {th }}$ tree was saved into a file. The log-likelihood scores of sample points were plotted against the number of generations using TRACER 1.0 (http://evolve.zoo.ox.ac.uk/ software.html) to determine that the stationarity was achieved when the log-likelihood values of the sample points reached a stable equilibrium value (Huelsenbeck \& Ronquist, 2001). The initial $1 \mathrm{~K}$ trees were discarded as a burn-in before calculating PPs. Using the "sumt" command of MrBAYES, the majority-rule consensus tree was calculated from $19 \mathrm{~K}$ trees sampled after reaching likelihood convergence to calculate the PPs. The phylogenetic tree was drawn using Treeview (Page, 1996) and edited in Adobe Illustrator CS3.

\section{Results}

The sequences obtained have been deposited within EMBL (http://www.ebi.ac.uk/embl) with the accession numbers indicated in Table 1 . It was not possible to obtain any sequences for some isolates since no PCR products were visualized from the agarose gel. From some collections (e.g. CEPSCL6 and SINSCL6) three similar sequences were obtained after cloning, but only one was included in the alignment. The new sequences of this study were aligned with four from the GenBank. A new Pisolithus sp. sequence was included as outgroup (Table 1). Sequences from two collections (UNSCL1 and CEPSCL5) were shorter and/or with weak peak in the electropherogram. These two sequences were excluded from the alignment; however, the sequence fragment of UNSCL1 was identical to SINSCL8 and the sequence fragment of CEPSCL5 was identical to CEPSCL6 and UNSCL7. The final alignment has a total of 38 sequences with 892 nonambiguously aligned sites. 641 characters were constant, 81 variable characters were parsimony-uninformative and 170 characters were parsimony-informative. Under a heuristic search 100 parsimonious trees were obtained with a length of 410 steps, $\mathrm{CI}=0.7439, \mathrm{RI}=$ 0.9147 and $\mathrm{RC}=0.6805$. In the consensus tree (Fig. 1) 
two main clade appeared; clade (I) and (11) respectively. These clades comprised 11 major terminal clades (a-k). Those Scleroderma collections with spiny basidiospores were grouped together in sub-clade $1 \mathrm{~A}$ and those collections with sub-reticulate basidiospores appeared together within sub-clade $1 \mathrm{~B}$. The collections with reticulate spores were grouped together in clade II. The Bayesian ITS analysis revealed basically the same topology as the parsimo- nious consensus tree in relation to the two main clades (tree not shown) with strong BS support (bold branches in Fig. 1).

The first sub-clade (1A) branched into 3 terminal clades (a, b \& c). Clade a (BS 90\% /PP1.0) consisted of $S$. cepa (CEPSCL6), a GenBank sequence under S. cepa (DQ453694) and one unidentified sample (UNSCL7) whilst one $S$. cepa collection (CEPSCL2) and one S. verrucosum (VERSCL4) are formed to-

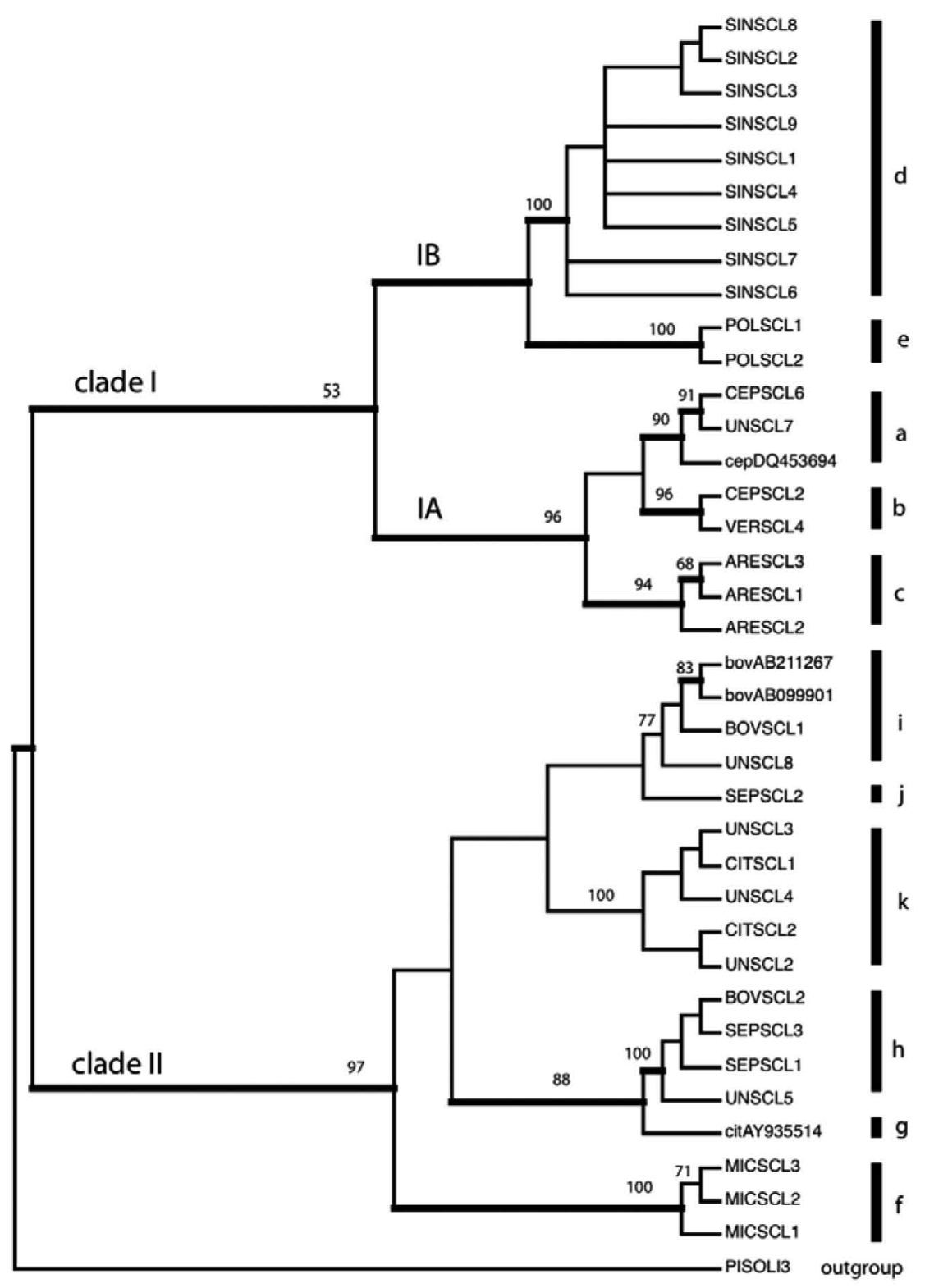

Fig. 1. Strict consensus tree of the 100 ITS trees obtained from heuristic search in the parsimony analysis. Bootstrap support values $(10,000$ replications) above $50 \%$ are shown at the nodes. Branches in bold print indicate significant statistical support in the Bayesian analysis (posterior probability $>0.85$ ). The 34 Scleroderma new sequences generated in this study are labeled with the isolation DNA code indicated in Table 1. The 4 sequences retrieved from the GenBank are indicated with the accession numbers. Pisolithus sp. was included as outgroup. 
gether in clade b (BS 96\% /PP0.99). All the S. areolatum samples are well separated in clade $\mathrm{c}$ with good supported (BS 94\% /PP1.00). However, the relationship between these taxa involved in this subclade IA is not well resolved since the clades $\mathrm{a}$ and $\mathrm{b}$ are not well supported and are sister groups in the parsimony tree (lesser than 50\% BS).

Sub-clade IB representing another two terminal clades. One clade (d) contained all Scleroderma described as $S$. sinnamariense from Thailand with significant

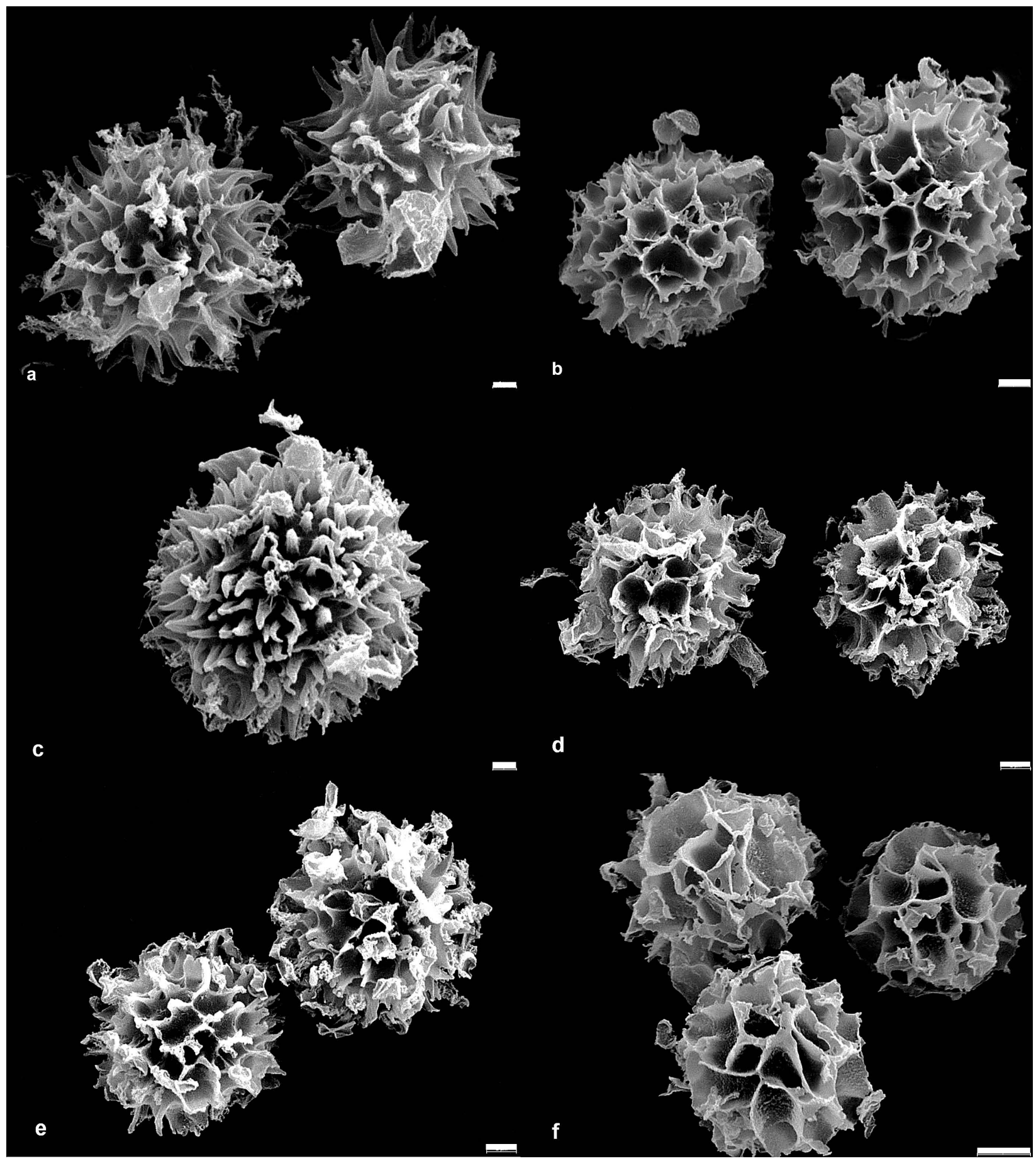

Fig. 2. Basidiospores of selected Scleroderma collections displaying theirs ornamentation confirmed subgenera proposed by Guzmán (1970). a, spiny ornamentation of $S$. areolatum (ARESCL2, bar $=1 \mu \mathrm{m})$; b, reticulate ornamentation of $S$. bovista $(B O V S C L 2$, bar $=2$ $\mu \mathrm{m})$; $\mathbf{c}$, spiny ornamentation of $\mathrm{S}$. cepa $(\mathrm{CEPSCL} 5, \mathrm{bar}=1 \mu \mathrm{m})$; $\mathbf{d}$, e, reticulate ornamentation of $\mathrm{S}$. citrinum $(\mathrm{CITSCL} 1, \mathrm{bar}=2 \mu \mathrm{m}$ and CITSCL2, bar $=2 \mu \mathrm{m}$, respectively); $\mathbf{f}$, reticulate ornamentation of $S$. michiganense (MICSCL1, bar $=5 \mu \mathrm{m}$ ). 




Fig. 3. Basidiospores of selected Scleroderma collections displaying theirs ornamentation confirmed subgenera proposed by Guzmán (1970). a, reticulate ornamentation of S. michiganense (MICSCL2, bar $=5 \mu \mathrm{m}$ ); $\mathbf{b}, \mathbf{c}$, sub-reticulate ornamentation of $S$. polyrhizum (POLSCL1, bar $=2 \mu \mathrm{m} \&$ POLSCL2, bar $=2 \mu \mathrm{m}$, respectively); $\mathbf{d}$, reticulate ornamentation of $S$. cf. septentrionale $(\mathrm{SEPSCL} 1$, bar $=5 \mu \mathrm{m})$; e $\& \mathbf{g}$, sub-reticulate ornamentation of S. sinnamariense (SINSCL7, bar $=1 \mu \mathrm{m} \&$ SINSCL9 bar $=2 \mu \mathrm{m}$, respectively); $\mathbf{f}$, reticulate ornamentation of Scleroderma sp. (UNSCL5, bar $=2 \mu \mathrm{m})$; $\mathbf{h}$, spiny ornamentation of Scleroderma sp. (UNSCL7, bar $=1 \mu \mathrm{m}$ ). 
support (BS 100\% /PP 1.00). In another terminal clade (e), S. polyrbizum from North America grouped together with the Thai collections in a well supported clade (BS 100\%/PP 1.00). These two terminal clades have sub-reticulate basidiospores.

Clade II included the collections with reticulate basidiospores. The clade ramified into several moderately to well-supported branches and terminal clades. It identified at least 6 main groups (f-i). The very well supported clade $\mathrm{f}$ (BS100\%/PP 1.00) that includes three identical sequences of Scleroderma michiganense Guzmán (MICSCL1, 2 \& 3) is the sister group of the rest of the collection in the parsimony analyses. However, in both analyses, the relationships within some clades are not well resolved. Apparently, the two species which are currently identified as $S$. bovista (BOVSCL in the trees) and S. septentrionale Jeppson (SEPSCL) appear in different terminal clades of the phylogenetic trees (Clades h, i \& j).

Clade h consisted of Scleroderma described as $S$. bovista (BOVSCL2), S. septentrionale (SEPSCL1 \& SEPSCL3), and Scleroderma sp. (UNSCL5). All samples came from the Great Lakes regions (North America) whilst a Genbank sequence described as S. citrinum from Spain (AY935514) was formed as a separated branch in clade g. Two Scleroderma sequences described from Japan as $S$. bovista (AB211267 \& AB099901), one S. bovista (BOVSCL1) from Spain and Scleroderma sp. (UNSCL8) from Hungary formed clade $i$, that was not well resolved in the parsimony analysis (BS 77\%). This clade is the sister group of a sample of $S$. septentrionale from Sweden (SEPSCL2); although this relation has not BS support (less 50\%). Moreover, in the Bayesian tree, SEPSCL2 grouped into clade i, also with low support (PP 0.62).

The Scleroderma citrinum from Scotland (UNSCL2, 3, 4) appeared along with $S$. citrinum (CITSCL $1 \& 2$ ) from North America in clade (k) with strongly supported values in both Bayesian (PP 1.00) and MP (BS 100\%) analyses.

\section{Discussion}

The information gleaned from the present sample of Scleroderma spp. confirms the robustness of the three subgenera proposed by Guzmán (1970). However, what is demonstrated is that even from the small sample of species examined during the present study there are still problems of identification within the genus. The classical species, $S$. areolatum Ehrenb.(c), S. bovista (i), S. cepa (a), S. citrinum (k), S. polyrbizum (e), S. sinnamariense (d) and $S$. verrucosum (b) form coherent groups along with the more recently described species $S$. michiganense (f) and S. septentrionale (j).
However, two units need to be reassessed in the future, a species close to $S$. bovista as understood in Europe which apparently has been found in North America and which includes material identified as both $S$. bovista and $S$. septentrionale (terminal clade h), and a sequence obtained from GenBank. CitAY935514 from Genbank was collected in Spain (Ruiz-Díez \& al., 2006) and identified as S. citrinum (g) which it is clearly not. The North American collections need to be carefully examined within a revision of other specimens from the Great Lakes region but this is something outside the scope of this present study. However, as a result of this study it is suggested that the North American group (terminal clade h) might represent western collections of $S$. meridionale Demoulin \& Malençon. This is a South European and North African taxon with reticulate basidiospores and pseudostipe which is characterised by a thick, golden yellow, furfuraceous peridium and a transversely furrowed and cracked pseudostipe. The peridium sometimes splits in a star-shaped way and thus shows similarities with some populations of $S$. bovista when overmature. It is apparently associated with evergreen oaks and Pinus spp. (Calonge 1998). Demoulin (1974) recognized S. meridionale from the Great Lakes region of North America and from coastal areas of North Carolina. According to Guzmán \& Ovrebo (2000), however, the same large Scleroderma of the Great Lakes sand dunes is identical with $S$. septentrionale, a species growing in sand-dune habitats, resembling $S$. bovista but with a quite distinct morphology. In the molecular analysis in the present study it is included in terminal clades i \& $\mathrm{h}$ in the tree.

From the above alignments it has been demonstrated that Scleroderma polyrbizum is immersed within the main body of Scleroderma despite the fact that it had been separated out in a distinct genus. The conclusions of Guzmán (1970) are therefore supported that Sclerangium Lev. is a synonym of Scleroderma. Sclerangium was erected (Léveille, 1848) to host $S$. polyrbizum which he considered quite distinct in the stellate dehiscence of the mature basidiome and retention of the exposed spore-mass centrally resembling that of an earthstar (Geastrum). This is undoubtedly the same reason why the epithet for $S$. geaster Fr. was erected but this species is generally agreed to be conspecific with $S$. polyrhizum. Massee (1889) also saw a difference when he erected the genus Stella for S. americana Mass., a synonym of S. stellatum Berk. (=Sclerangium brasiliense Henn. \& Nepotatus stellatus Lloyd and Scleroderma bermudense Coker but not Lycoperdon stellatum =Astraeus). 
Scleroderma polyrbizum must be considered the type of the genus Sclerangium and therefore by default sg. Sclerangium (Lev.) Guzman as defined by Guzmán (1970). Thus $S$. polyrbizum based on two collections from North America and $S$. sinnamariense based on nine different analyses of the same population sit neatly between the two subgenera mentioned earlier.

S. sinnamariense is widespread in the tropics commonly occurring in Thailand, Malaysia, Indonesia and the Philippines. It is also known from Fiji, Central America, New Guinea, etc. (Guzmán, 1970; Watling \& Sims, 2004). It has been found with the so-called Astraeus bygrometricus (Pers.) Morgan and Pisolithus arbizus (Pers.) Rauschert. One of us (RW) judging from the subtle differences in macromorphology of $S$. sinnamariense that it will prove to be a complex of taxa. In the present study only a single population was used to anchor the study.

\section{Acknowledgements}

We thank the curators of the Royal Botanic Garden, Edinburgh, Scotland (E), BCN, Spain and A.D. Parker (Waukesha, USA) for the loan of specimens. CP is indebted to the Commission on Higher Education of Thailand, Royal Thai government for financial support and to the European Commission Human Potential Programme for supporting part of this study at the Real Jardín Botánico de Madrid (BIODIBERIA).

\section{References}

Binder, M. \& Bresinsky, A. 2002. Derivation of a polymorphic lineage of gasteromycetes from boletoid ancestors. Mycologia 94 : 85-98.

Calonge, F.D. 1998. Gasteromycetes, I. Lycoperdales, Nidulariales, Phallales, Sclerodermatales, Tulostomatales. Flora Mycologica Iberica vol. 3. Real Jardín Botánico \& J. Cramer. Madrid, Berlin, Stuttgart. $271 \mathrm{pp}$.

Demoulin, V. 1974. Scleroderma meridionale Demoulin et Malençon, the correct name for the large Scleroderma of Great Lakes sand dunes. The Michigan Botanist 13: 68-72.

Felsenstein, J. 1985. Confidence limits on phylogenies: An approach using the bootstrap. Evolution 39 783-791.

Fries, E. 1821. Systema Mycologium. Gryphiswaldiae. 520 pp.

Gardes, M. \& Bruns, T.D. 1993. ITS primers with the enhanced specificity for basidiomycetes-application to the identification of mycorrhizae and rusts. Molecular Ecology 2: 113-118.

Guzmán, G. 1970. Monografia del género Scleroderma Pers. Emend. Fr. Darwiniana 16: 233-407.

Guzmán, G. \& Ovrebo, C.L. 2000. New observations on sclerodermataceous fungi. Mycologia 92(1): 174-179.

Hawksworth, D.L., Kirk, P.M., Sutton, B.C. \& Pegler, D.N. 1995. Ainsworth and Bisby's dictionary of the fungi, $8^{\text {th }}$ edn. CAB international, Wallingford.
Huelsenbeck, J.P., Rannala, B. \& Masly, J.P. 2000. Accomodating phylogenetic uncertainty in evolutionary studies. Science 288: 2349-2350.

Huelsenbeck, J.P. \& Ronquist, F. 2001. MRBAYES: Bayesian inference of phylogenetic trees. Bioinformatics 17: 754-755.

Larget, B. \& Simon, D.L. 1999. Markov chain Monte Carlo algorithms for the Bayesian analysis of phylogenetic trees. Molecular Biology and Evolution 16: 750-759.

Léveillé, J.H. 1848. Fragments Mycologiques. Annales Des Sciences Naturelles (Sér. III): 119-144.

Marx, D.H. 1981. Variability in ectomycorrhizal development and growth among isolate of Pisolithus as affected by source, age and reisolation. Canadian Journal of Forest Research 11: 168-174.

Massee, G. 1889. A monograph of the British Gasteromycetes. Annual of Botany 4: 1-104

Martin, F., Díez, J., Dell, B. \& Delaruelle, C. 2002. Phylogeography of the ectomycorrhizal Pisolithus species as inferred from nuclear ribosomal DNA ITS sequences. New Phytologist 153: 345-357.

Martín, M.P. \& García-Figueres, F. 1999. Colletotrichum acutatum and C. gloeosporioides cause anthracnose on olives. European Journal of Plant Pathology 105: 733- 741.

Martín, M.P. \& Winka, N. 2000. Alternative methods of extracting and amplifying DNA from lichens. Lichenologist 32: 189-196.

Persoon, C.H. 1801. Synopsis methodica fungorum. Göttingen. 706 pp.

Rodriguez, F., Oliver, J.F., Martín, A. \& Medina, J.R. 1990. The general stochastic model of nucleotide substitution. Journal of Theororetical Biology 142: 485-501.

Ruiz-Díez, B., Rincón, A.M., de Felipe, M.R., \& FernándezPascual, M. 2006. Molecular characterization and evaluation of mycorrhizal capacity of Suillus isolates from Central Spain for the selection of fungal inoculants. Mycorrhizas 16(7): 465-474.

Page, R.D.M. 1996. Treeview: an application to display phylogenetic trees on personal computers. Computer Application in the Biosciences 12: 357-358.

Sambrook, J., Fritsch, E.F. \& Maniatis, T. 1989. Molecular Cloning. A laboratory manual, $2^{\text {nd }}$ edn. Cold Springer Habour Laboratory Press, New York.

Šebek, S. 1953. Monograph of the Central European Species of the Genus Scleroderma Pers. Sydowia 7: 158-190.

Sims, K., Watling, R. \& Jeffries, P. 1995. A revised key to the genus Scleroderma. Mycotaxon 56: 403-420.

Swofford, D.L. 2003. PAUP:. Phylogenetic analysis using parsimony ("and other methods), Version 4.0b10. Sinauer Associates: Sunderland, MA, USA.

Vaillant, S. 1727. Botanicon Parisiense, [31] + XII + [4] + $205+$ $[12]+[1]$ p. XXXIII tab.; 1 portr., 1 carte.

Watling, R. \& Sims, K. 2004. Taxonomic and floristic notes on some Malaysian fungi IV (Scleroderma). In: Cripps, C.L. (ed.), Fungi in Forest Ecosystems; Systematics, Diversity and Ecology. Memoirs of the New York Botanical Garden 89: 93-96.

White, T.J., Bruns, T.D., Lee, S.B. \& Taylor, J.W. 1990. Amplification and direct sequencing of fungal ribosomal RNA genes for phylogenetics. PCR protocol, A guide to methods and applications. Academic press, San Diego, CA, pp. 315-321.

Received: 26-VII-2008

Accepted: 3-XI-2008 